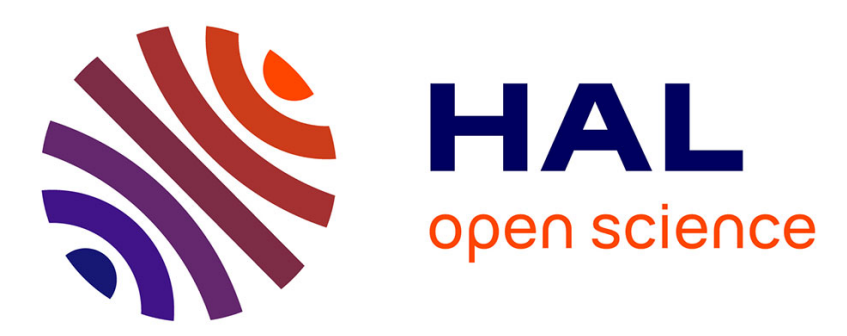

\title{
Determination of naturally occurring estrogens and androgens in retail samples of milk and eggs
}

Frédérique Courant, Jean-Philippe Antignac, Daniel Maume, Fabrice

Monteau, François André, Bruno Le Bizec

\section{- To cite this version:}

Frédérique Courant, Jean-Philippe Antignac, Daniel Maume, Fabrice Monteau, François André, et al. Determination of naturally occurring estrogens and androgens in retail samples of milk and eggs. Food Additives and Contaminants, 2007, 24 (12), pp.1358-1366. 10.1080/02652030701329637 . hal00577452

\section{HAL Id: hal-00577452 \\ https://hal.science/hal-00577452}

Submitted on 17 Mar 2011

HAL is a multi-disciplinary open access archive for the deposit and dissemination of scientific research documents, whether they are published or not. The documents may come from teaching and research institutions in France or abroad, or from public or private research centers.
L'archive ouverte pluridisciplinaire HAL, est destinée au dépôt et à la diffusion de documents scientifiques de niveau recherche, publiés ou non, émanant des établissements d'enseignement et de recherche français ou étrangers, des laboratoires publics ou privés. 


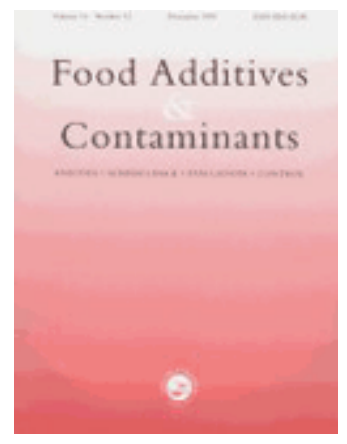

\section{Determination of naturally occurring estrogens and androgens in retail samples of milk and eggs}

\begin{tabular}{|r|l|}
\hline Journal: & Food Additives and Contaminants \\
\hline Manuscript ID: & TFAC-2007-029.R1 \\
\hline Manuscript Type: & Original Research Paper \\
\hline Methods/Techniques: & GC/MS \\
\hline Additives/Contaminants: & Oestrogens, Residues, Veterinary drug residues - anabolic steroids \\
\hline Food Types: & Eggs, Milk \\
\hline
\end{tabular}

SCHOLARONE $^{\text {TM }}$ Manuscripts 
Determination of naturally occurring estrogens and androgens in retail samples of milk and eggs

Frédérique COURANT, Jean-Philippe ANTIGNAC, Daniel MAUME, Fabrice MONTEAU, François ANDRE, and *Bruno LE BIZEC

LABERCA-Ecole Nationale Vétérinaire de Nantes, Route de Gachet, BP 50707, F44307 NANTES, Cedex 3, France

* Author to whom correspondence should be addressed:

Pr Bruno LE BIZEC

LABERCA, Ecole Nationale Vétérinaire de Nantes

BP 50707, Route de Gachet, 44307-NANTES Cedex 3

FRANCE

Tel: 0033240687880

Fax: 0033240687878

E-Mail: laberca@vet-nantes.fr 


\begin{abstract}
The occurrence of the main steroid hormones (estrone, 17 $\alpha$-estradiol, 17 $\beta$-estradiol, 17 $\alpha$-testosterone, 17 $\beta$-testosterone, dehydroepiandrosterone, 4-androstenedione), especially in milk and eggs, was investigated. An analytical method based on GCMS/MS was developed for steroid measurement at ultra-trace level in food products. The limits of detection for estrogens were found to be about 5 and $30 \mathrm{ng} \mathrm{kg}^{-1}$ in milk and eggs respectively. For androgens, the limits of detection were around 10 and $50 \mathrm{ng}$ $\mathrm{kg}^{-1}$ in milk and eggs respectively. The method was applied to milk and egg samples collected in a French supermarket. In milk, estrone was found at levels between 100 and $300 \mathrm{ng} \mathrm{L}{ }^{-1}$, while $17 \beta$-estradiol levels were estimated near $20 \mathrm{ng} \mathrm{L}^{-1} \cdot 17 \alpha$-testosterone was found from $50 \mathrm{ng} \mathrm{L}^{-1}$ in skim milk to $85 \mathrm{ng} \mathrm{L}^{-1}$ in whole milk. In egg samples, estrone and $17 \beta$-estradiol were found at 1.5 and $0.9 \mu \mathrm{g} \mathrm{kg}^{-1}$, respectively, while $17 \alpha$ estradiol was found to be in lower concentrations (i.e. around $0.55 \mu \mathrm{g} \mathrm{kg}-1$ ). Regarding androgens, $17 \alpha$ and $17 \beta$-testosterone were estimated at 1.9 and $1.3 \mu \mathrm{g} \mathrm{kg}{ }^{-1}$, respectively. These results represent a first attempt to estimate the food exposure to steroid hormones. In the future, the collection of additional data should permit the comparison between this exogenous dietary intake and the daily endogenous production in pre-pubertal children, as a basis of risk assessment regarding endocrine disruption linked to these molecules for this critical population.
\end{abstract}

Keywords: children, egg, milk, GC-MS/MS, estrogens, androgens 


\section{Introduction}

Global concern has been raised in recent years over the adverse effects that may result from exposure to chemicals that may interfere with the endocrine system. Among the different classes of substances that have been pointed out (dioxins, phytosanitary products, phytoestrogens, hormones...), steroid hormones largely remain the most biologically active compounds. A specific concern is related to low-dose effects and long-term exposure consequences, especially for specific populations at critical stage of development (foetus, new born, prepubertal children).

In the field of toxicological substances used in food-producing animals, the US Food and Drug Administration ruled that ' ... no physiological effect will occur in individuals chronically ingesting animal tissues that contain an increase of endogenous steroid equal to $1 \%$ or less of the amount in micrograms produced by daily synthesis in the segment of the population with the lowest daily production' (FDA, 1999). Regarding naturally occurring hormones such as estradiol, daily production rate (PR) and exogenous intake are the crucial elements of a risk assessment. The main measurable parameter linked to the daily production rate is the plasmatic circulating hormone concentration. The first reports on estradiol concentrations in serum from pre-pubertal children, which were obtained using radioimmunoassay, were published in the 1970s (Jenner et al. 1972, Bidlingmaier et al. 1973, Angsusingha et al. 1974). According to these reports, the levels of estradiol in this population were ranging from 22 to 41 pmol L $\mathrm{L}^{-1}$. However, the plasma levels of estradiol in these studies appeared in most cases below or close to the detection limit of those assays. More recent comparisons of these radioimmunoassay data with results obtained by more specific techniques seems 
to indicate a tendency of the earlier methods to overestimate the estradiol concentrations (Ikegami et al. 2001, Juul 2001, Nelson et al. 2004). Consequently, a re-evaluation of these plasmatic hormonal levels using a very sensitive and specific confirmatory measurement technique (GC-MS/MS and /or GC-HRMS) appeared today relevant. The authors already initiated this work and the first results confirmed that estrogens endogenous level in prepubertal children is unsurprisingly extremely low (Courant et al. 2007) and significantly lower than the commonly admitted values. Consequently, even a small exogenous intake would account for a major change in the total activity of the involved hormone, which is reflected in phenotypic effects in the child (Aksglaede et al. 2006). Thus, food intake is presumed to contribute significantly to the daily exposure. There is no doubt about the presence of steroid hormones in food of animal origin (Hartmann et al. 1998, Andersson et al. 1999, Daxenberger et al. 2001). These different authors reviewed most of articles dealing with natural occurrence of sex steroid hormones in food products. They noticed that pork, meat products, fish and poultry contain similar amounts of steroids as cattle (in the $\mathrm{ng} \mathrm{kg}^{-1}$ range). They observed that milk products and eggs are an important source of steroids. Nevertheless, it must be noticed that concentrations reported for various animal tissues were mainly determined by the same methods suspected to over-estimate the very weak concentrations of steroid hormones in biological fluids. Indeed, problems in measuring low levels of steroids precisely have been recognized by studies showing high variation in the concentrations obtained between different assay methods and different laboratories (Potischman et al. 1994, Carlström 1996). Thus, a new accurate evaluation of steroids levels present in the most contributing food, e.g. milk and eggs, appears relevant. Our main purpose was to investigate to what extent steroid hormones in food may represent a risk of endocrine 


\section{Materials and methods}

\section{Reagents and chemicals}

All solvents and reagents were of analytical or HPLC grade quality (SDS, Peypin, France). All SPE (ChromP, SiOH) were single use cartridges (SDS, Peypin, France). Purified Helix pomatia preparation was used for steroid deconjugation (Sigma, St Louis, MO, USA). N-methyl-N-(trimethylsilyl)-trifluoroacetamide (MSTFA), N,O-Bis (trimethylsilyl)-trifluoroacetamide (BSTFA), and pentafluorobenzylbromide (PFBBr) were purchased from Fluka (Buchs, Switzerland). Dithiothreitol (DTE) and trimethyliodosilane (TMIS) were purchased from Sigma-Aldrich (St. Quentin Fallavier, France). Standard reference steroids were purchased from Sigma (St Louis, MO, USA) and deuterated internal standards were provided by Steraloids (Wilton, NY, USA).

\section{Samples}

Milk (whole, half-skim, and skim) samples $(n=12)$ and egg samples $(\mathrm{n}=8)$ were commercial products collected in a French supermarket.

\section{Samples preparation}

Milk samples $(3 \mathrm{~mL})$ were spiked with $300 \mathrm{pg}$ of internal standard (17 $\beta$-estradiol- $\mathrm{d}_{3}$ and methyltestosterone- $\mathrm{d}_{3}$ for estrogens and androgens, respectively). The first steps in the 
sample preparation procedure (enzymatic hydrolysis of phase II metabolites, liquidliquid extraction with ether and purification onto SPE ChromP cartridge) have been previously described (Courant et al., 2007). The extracts were then evaporated to dryness $\left(\mathrm{N}_{2}, 45^{\circ} \mathrm{C}\right)$, and resuspended in $0,5 \mathrm{~mL}$ of $1 \mathrm{M}$ sodium hydroxide. Thus, a liquid-liquid extraction was performed at $\mathrm{pH} 14$ with $2 \times 4 \mathrm{~mL}$ hexane:diethylether (70:30, v/v), permitting the specific extraction of androgens. The $\mathrm{pH}$ of the aqueous layer was then adjusted to 5.2 with glacial acetic acid $(150 \mu \mathrm{L})$ and a second liquidliquid extraction was carried out using $2 \times 4 \mathrm{~mL}$ diethyl ether in order to extract estrogens. Both fractions (A and E) were evaporated to dryness and resuspended in dichloromethane $(200 \mu \mathrm{L})$ and n-hexane $(300 \mu \mathrm{L})$. They were then applied onto a SiOH SPE column (1 g) previously conditioned with $18 \mathrm{~mL}$ n-hexane. The cartridge was washed with n-hexane:ethyl acetate $(85: 15, \mathrm{v} / \mathrm{v})(5 \mathrm{~mL}$ for estrogens, $10 \mathrm{~mL}$ for androgens) before elution of target analytes with $13 \mathrm{~mL}$ n-hexane:ethyl acetate (60:40, v/v). The collected fractions were evaporated to dryness $\left(45^{\circ} \mathrm{C}, \mathrm{N}_{2}\right)$. Dry residues were finally resuspended in $50 \mu \mathrm{L}$ n-hexane:isopropanol $(90: 10, \mathrm{v} / \mathrm{v})$ or $50 \mu \mathrm{L} \mathrm{n}$ hexane:isopropanol (85:15, v/v) for androgens and estrogens, respectively. As an ultimate purification step, the fractions were injected onto a HPLC system. Collected target fractions were evaporated to dryness $\left(45^{\circ} \mathrm{C}, \mathrm{N}_{2}\right)$ and $300 \mathrm{pg}$ of external standard (estriol and norgestrel for estrogens and androgens respectively) were added.

Egg samples- Freeze-dried egg samples $(500 \mathrm{mg})$ were dissolved in $2 \mathrm{~mL}$ water and incubated with $500 \mathrm{pg}$ of internal standard $\left(17 \beta\right.$-estradiol- $\mathrm{d}_{3}$ and methyltestosterone- $\mathrm{d}_{3}$ for estrogens and androgens, respectively). Liquid/liquid extraction (LLE) with $2 \times 10 \mathrm{~mL}$ methanol/acetone $(1: 1, \mathrm{v} / \mathrm{v})$ was then performed for extraction of steroids (free + conjugates). Organic layers were combined and evaporated to $2 \mathrm{~mL}$ at $45^{\circ} \mathrm{C}$ under a 
gentle stream of nitrogen. $2 \mathrm{~mL}$ of $2 \mathrm{M}$ acetate buffer $(\mathrm{pH} 5.2)$ and $200 \mu \mathrm{L}$ of $\beta$ glucuronidase from Helix pomatia were added to the samples. The enzymatic hydrolysis was carried out overnight at $52^{\circ} \mathrm{C}$. The rest of the procedure was identical as the one described for milk samples. After HPLC fractionation, the collected extracts were evaporated to dryness $\left(45^{\circ} \mathrm{C}, \mathrm{N}_{2}\right)$ and $500 \mathrm{pg}$ of external standard (estriol and norgestrel for estrogens and androgens respectively) were added.

\section{Semi preparative HPLC}

The HPLC system used was a Hewlett-Packard HP-1100 pump equipped with a fraction collector and UV-detector (DAD, diode array detector) operating from 200 to $280 \mathrm{~nm}$. A 3-(dimethylamino)propyl-functionalized silica gel column (EC-Nucleosil 100-5 $\mathrm{N}\left(\mathrm{CH}_{3}\right)_{2}$-propyl, $\left.250 \times 4 \mathrm{~mm}, 5 \mu \mathrm{m}\right)$ from Macherey-Nagel (Hoerdt, France) held at $50^{\circ} \mathrm{C}$ was used for semi-preparative purification. Mobile phase was a mixture of $\mathrm{n}$ hexane (solvent A) and isopropanol (solvent B). Mobile phase composition (A:B; v/v) was 96:4 at $0 \mathrm{~min}$. Two different gradients were applied depending on the analytes. For androgens, the initial mobile phase composition was kept during $15 \mathrm{~min}$, then linearly changed to reach $20: 80$ at $19 \mathrm{~min}$ and maintained until $28 \mathrm{~min}$. For estrogens, the mobile phase composition $A: B$ was linearly changed from 0 to 15 min from $96: 4$ to $85: 15$, then modified so that the mobile phase reached 20:80 at 19 min, and finally kept unchanged until $9 \mathrm{~min}$. Flow rate was set at $1 \mathrm{~mL} / \mathrm{min}$ and injected volume was $50 \mu \mathrm{L}$.

\section{Derivatisation reaction}

Derivatisation of the androgen fraction was carried out with $20 \mu \mathrm{L}$ of a mixture MSTFA/TMIS/DTE (1000:5:5; v/v/w) during $40 \mathrm{~min}$ at $60{ }^{\circ} \mathrm{C}$. Derivation of the 
estrogen fraction with PFBBr / BSTFA has been previously described (Courant et al., 2007). Both final extracts $(2 \mu \mathrm{L})$ were injected onto the GC-MS/MS system.

\section{GC-MS/MS measurement}

Estrogens measurements were carried out by GC-MS/MS with negative chemical ionisation (NCI) using methane as reagent gas. A HP-6890 gas chromatograph was coupled to a VG-QuattroII® or QuattroMicro GC® (Waters-Micromass, Manchester, UK) triple quadrupole device. Injector and transfer line temperatures were set at $250^{\circ} \mathrm{C}$ and $280^{\circ} \mathrm{C}$, respectively. Source and analyser temperatures were set to $280^{\circ} \mathrm{C}$ and $100{ }^{\circ} \mathrm{C}$, respectively. GC column was a $30 \mathrm{~m}$ x $0.25-\mathrm{mm}$ id., film thickness $0.25 \mu \mathrm{m}$, ZB-5MS (Zebron). Temperature programme was set as follows: $120^{\circ} \mathrm{C}(2 \mathrm{~min})$, $15^{\circ} \mathrm{C} \min ^{-1}$ until $280^{\circ} \mathrm{C}(0 \mathrm{~min}), 5^{\circ} \mathrm{C} \min ^{-1}$ until $320^{\circ} \mathrm{C}(6 \mathrm{~min})$. Helium (N55) was used as carrier gas at $1 \mathrm{~mL} \cdot \mathrm{min}^{-1}$. Electron energy was set at $40 \mathrm{eV}$.

Androgens measurements were carried out using GC-MS technique. However, positive electronic ionisation was preferred as ionisation for this steroid group. Electron energy was set at $70 \mathrm{eV}$. Temperature programme was set as follows: $120^{\circ} \mathrm{C}(2 \mathrm{~min})$, $15^{\circ} \mathrm{C} \min ^{-1}$ until $250^{\circ} \mathrm{C}(0 \mathrm{~min}), 5^{\circ} \mathrm{C} \min ^{-1}$ until $300^{\circ} \mathrm{C}$ (5 min). Injection volume was 2 $\mu \mathrm{L}$ (purge splitless 1,5 $\mathrm{min}$ ). The mass spectrometer was operated in the multiple reaction monitoring (MRM) acquisition mode. Argon was used as collision gas at 4.5.10 ${ }^{-4}$ mbar. Table I summarizes the retention times (RT values), transitions and collision energies used for each monitored molecule.

[Insert table I about here] 


\section{Quantification procedure}

Standard extracted calibration curves were established by adding a fixed amount of internal standard (i.e. $300 \mathrm{pg}$ for milk samples and $500 \mathrm{pg}$ for egg samples) to $3 \mathrm{~mL}$ water and increasing quantities of the target analytes ranging from 0.03 to $1.5 \mathrm{ng}$ for milk and from 0.05 to $25 \mathrm{ng}$ for eggs. Samples were then extracted and derivatised as described here before.

\section{Results \\ Validation data}

Linearity. The response linearity was found to be satisfactory with $\mathrm{R}^{2}$ values better than 0.99 for all the target analytes. Calibration curves obtained in egg samples for estrogens and androgens are represented in figure $1 \mathrm{a}$ and $1 \mathrm{~b}$, respectively.

Performance limits. Limit of detection (LOD) and limit of quantification (LOQ) for each analyte were classically determined on the basis of concentration inducing signal/noise ratio of 3 and 6 , respectively. LOD for estrogens were found to be near 5 and $30 \mathrm{ng} \mathrm{kg}^{-1}$ in milk and egg sample respectively. For androgens, LOD were around 10 and $50 \mathrm{ng} \mathrm{kg}^{-1}$ in milk and egg samples respectively. LOQ were found to be twice than LOD.

[Insert figure 1 about here]

Specificity. Figure 2a shows an example of a typical ion chromatogram obtained for a milk sample in which $17 \alpha$-testosterone and $17 \beta$-testosterone were quantified at 87 and 
$13 \mathrm{ng} \mathrm{kg}^{-1}$, respectively. Androstenedione (lower trace) was quantified at $536 \mathrm{ng} \mathrm{kg}^{-1}$. The complexity and final selectivity of the purification strategy (4 steps) produced a clean extract with no interference detected at ions monitored for androgens by GC-(EI)MS/MS. Figure $2 \mathrm{~b}$ shows an example of a typical ion chromatogram obtained for an egg sample in which $17 \alpha$-estradiol and $17 \beta$-estradiol were quantified at 0.85 and 0.87 $\mu \mathrm{g} \mathrm{kg}{ }^{-1}$, respectively. The specificity in term of absence of interfering compounds appearing on the ion chromatograms is greatly improved by the use of GC-(NCI)MS/MS but clearly also by the efficient purification process.

[Insert figure 2 about here]

Repeatability. The repeatability was calculated on the basis of the $17 \beta$-estradiol- $\mathrm{d}_{3}$ and Methyltestosterone- $\mathrm{d}_{3}$ internal standard signals. Indeed, the presence and variability of natural estrogens in milk and egg made difficult this evaluation on the native target analytes. $17 \beta$-estradiol- $\mathrm{d}_{3}$ and Methyltestosterone- $\mathrm{d}_{3}$ were added to $3 \mathrm{~mL}$ milk sample (300 pg equivalent to a $100 \mathrm{ng} \mathrm{L}^{-1}$ concentration in milk) and to $0.5 \mathrm{~g}$ egg sample (500 pg equivalent to $1 \mu \mathrm{g} \mathrm{kg}^{-1}$ concentration in egg). These fortified samples were treated as described above, with a final GC-(NCI)-MS/MS measurement and GC-(EI)-MS/MS measurement for estrogens and androgens, respectively. Ten replicates of these experiments were carried out. The repeatability was found to be satisfactory with an RSD of around $20 \%$ for the target compounds in the two matrices. Considering the actual current EC regulation regarding analytical criteria for steroid residues analysis in food (2002/657/CE), these values appears in accordance with the maximal variability 
[Insert Table IIa about here]

Estrone (E1) was quantified at levels in-between 100 and $300 \mathrm{ng} \mathrm{L}^{-1} .17 \alpha$-estradiol and $17 \beta$-estradiol levels (17 $\alpha$-E2 and $17 \beta$-E2) were estimated near $40 \mathrm{ng} \mathrm{L}^{-1}$. A comparison between hydrolysed and non-hydrolysed samples demonstrated that estrogens were found mainly as phase II conjugated metabolites $(>90 \%)$. As a consequence, estrogens seem to be present essentially in the aqueous fraction of milk, explaining that no major relation was found between the observed concentrations and the fat content of the samples. Results obtained for androgens (for whole, half-skim milk and skim milk) are presented in table IIb. In opposition with estrogens, $\alpha$-testosterone, 4-androstenedione (AED) and free dehydroepiandrosterone (DHEA) contents appeared linked to the milk fat content. Total $17 \alpha$-testosterone (free + phase II conjugated metabolites) was quantified from $50 \mathrm{ng} \mathrm{L}^{-1}$ in skim milk (25 - $30 \%$ of conjugated forms) to $85 \mathrm{ng} \mathrm{L}^{-1}$ in whole milk ( $<10 \%$ of conjugated forms). Considering the actual LOD of the method used, only total $17 \beta$-testosterone (average around $10 \mathrm{ng} \mathrm{L}^{-1}$ ) was quantified in these samples. 
[Insert Table IIb about here]

Egg samples. Results obtained for estrogens and androgens are presented in Table III. On the basis of these preliminary measurements, estrone and $17 \beta$-estradiol were quantified at 1.5 and $0.9 \mu \mathrm{g} \mathrm{kg}^{-1}$ respectively. $17 \alpha$-estradiol was found to be in lower concentrations than $17 \beta$-estradiol (i.e. around $0.55 \mu \mathrm{g} \mathrm{kg}-1$ ). Regarding androgens, $17 \alpha$ and $17 \beta$-testosterone were estimated at 1.9 and $1.3 \mu \mathrm{g} \mathrm{kg}^{-1}$, respectively. Free DHEA was quantified at $1.5 \mu \mathrm{g} \mathrm{kg}^{-1}$. 4-androstenedione was found to be in higher concentrations compared to the other measured compounds (near $85 \mu \mathrm{g} \mathrm{kg}^{-1}$ ).

[Insert Table III about here]

\section{Discussion}

In milk

Due to the relative permeability of the blood/milk barrier, lipophilic hormones circulating in blood plasma may transfer in milk. Therefore, the estrogen content of milk is supposed to reflect the physiological state of the lactating animal. Narendran et al. studied estrogen concentrations in milk during the estrous cycle by radioimmunoassay. During most of the estrous cycle, estrogen concentrations remained

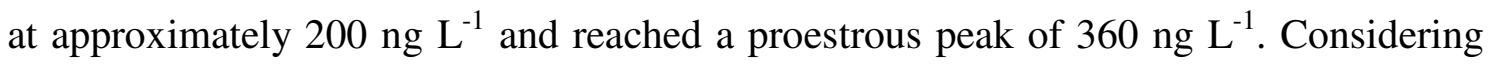
that commercial milks are in fact mixtures of milk collected on different animals, the great variability observed in term of hormone concentrations is not really surprising. Additional analyses are on going in the laboratory in order to continuously improve the statistical representativeness of this data set, especially by taking into account the 
influence of the physiological state, alimentation and age of lactating animals. A second observation was that estrogens were found mainly as phase II conjugated metabolites, which was already noticed by other authors. Saumande et al. developed in 1984 a radioimmunoassay for free $17 \beta$-estradiol, conjugated $17 \beta$-estradiol and total (free + conjugated) $17 \beta$-estradiol in defatted milk of cows. They found that concentrations of conjugated $17 \beta$-estradiol were higher than those of the free $17 \beta$-estradiol. McGariggle et al. also demonstrated with RIA that conjugated estrogens comprised more than $90 \%$ of the total human breast milk. Only few reports deal with androgens in milk. Contents reported are 20-150 ng L ${ }^{-1}$ testosterone (Hoffmann et al. 1977, Gaiani et al. 1984) and 100 to $3500 \mathrm{ng} \mathrm{L}^{-1}$ androstenedione (Gaiani et al. 1984). Values obtained in our study appeared in accordance with these data. At the contrary, Hoffmann et al. found that the ratio between free testosterone and conjugated testosterone in milk was about 1:1, while in the present study testosterone was found to be mainly unconjugated (70-90\%).

\section{In eggs}

Maternal transfer of nutrients, including steroid hormones, to embryos during gestation in viviparous amniotes is well known, but the underlying process is poorly understood (Janzen et al. 1998). A very significant transfer of $17 \beta$-estradiol and testosterone into the egg yolk was observed in oviparous animal (Lipar et al. 1999). French et al. studied steroid contents in egg collected from two colonies of common terns by radioimmunoassay. 4-androstenedione concentrations differed between the geographic sites and with egg-laying order (from 200 to $500 \mu \mathrm{g} \mathrm{kg}^{-1}$ ) whereas testosterone concentrations did not vary between the two different colonies (only with egg-laying order: from 5 to $12 \mu \mathrm{g} \mathrm{kg}^{-1}$ ). Estradiol concentrations were below the limit of detection 
$\left(0,1 \mu \mathrm{g} \mathrm{kg}^{-1}\right)$ for $70 \%$ eggs and considering only eggs with measurable estradiol, mean concentration was near $0,4 \mu \mathrm{g} \mathrm{kg}^{-1}$. Petrie et al. compared hormone concentrations in the avian yolks of male and female eggs and found that these were significantly different; estradiol varying from $0,4 \mu \mathrm{g} \mathrm{kg}^{-1}$ in male to $0,8 \mu \mathrm{g} \mathrm{kg}^{-1}$ in female while $17 \beta$ testosterone was quantified from $1,2 \mu \mathrm{g} \mathrm{kg}^{-1}$ in female to $2 \mu \mathrm{g} \mathrm{kg}^{-1}$ in male. Hartmann et al. using GC-MS quantified in eggs from domestic fowl (Gallus gallus) estradiol, estrone and testosterone to $0,2 \mu \mathrm{g} \mathrm{kg}^{-1}, 0,9 \mu \mathrm{g} \mathrm{kg}-1$ and $0,5 \mu \mathrm{g} \mathrm{kg}$ respectively. All these results from different authors indicate that there is a great variability in steroid concentrations from one egg to another depending on sex, sites, and egg laying order. This can explain the high standard deviation observed in our preliminary results.

\section{Conclusions}

An analytical method was developed for steroid measurement at ultra-trace level in food products. On one hand, the application of the developed method to sera samples confirmed that estrogens endogenous levels in pre-pubertal children are unsurprisingly extremely low (Courant et al. 2007). On the other hand, this method was applied to milk samples and egg samples collected in a French supermarket. In milk, estrone was quantified at levels in-between 100 and $300 \mathrm{ng} \mathrm{L}^{-1}$, while $17 \beta$-estradiol levels were estimated near $20 \mathrm{ng} \mathrm{L}^{-1} \cdot 17 \alpha$-testosterone was quantified from $50 \mathrm{ng} \mathrm{L^{-1 }}$ in skim milk to $85 \mathrm{ng} \mathrm{L}^{-1}$ in whole milk. In egg samples, estrone and $17 \beta$-estradiol were quantified at 1.5 and $0.9 \mu \mathrm{g} \mathrm{kg}^{-1}$, respectively, while $17 \alpha$-estradiol was found to be in lower concentrations (i.e. around $0.55 \mu \mathrm{g} \mathrm{kg}-1$ ). Regarding androgens, $17 \alpha$ and $17 \beta$ testosterone were estimated at 1.9 and $1.3 \mu \mathrm{g} \mathrm{kg}^{-1}$, respectively. 
These results represent a first attempt to estimate the food intake in steroid hormones for pre-pubertal children. Analyses are on going in our lab to collect additional data regarding plasmatic hormonal rates and steroid residues in food. In next future, these data are expected to be used for establishing a probabilistic modeling of exposure in which children ages (linked to endogenous production), consummation levels and residue concentrations will be taken into account. Our final objective will be the comparison between the dietary intake in steroid hormones (especially estrogens) and the daily endogenous production of prepubertal children, as a basis of risk assessment regarding endocrine disruption linked to these molecules for this critical population.

\section{References :}

Aksglaede L, Juul A, Leffers H, Skakkebaek NE, Andersson AM. 2006. The sensitivity of the child to sex steroids: possible impact of exogenous estrogens. Human Reproduction Update 12:341-349.

Andersson A, Skakkebaek N. 1999. Exposure to exogenous estrogens in food: possible impact on human development and health. European Journal of Endocrinology 140:477485 .

Angsusingha K, Kenny F, Howard. 1974. Unconjugated estrone estradiol and FSH and LH in prepubertal and pubertal males and females. Journal of Clinical Endocrinology and Metabolism 39:63-68. 
Bidlingmaier F, Wagner-Barnack M, Butenandt O. 1973. Plasma estrogens in childhood and puberty under physiologic and pathologic conditions. Pediatric Research 7:901-907.

Courant F, Antignac JP, Maume D, Monteau F, Andersson AM, Skakkebaek N, André F, Le Bizec B. 2007. Exposure assessment of prepubertal children to steroid endocrine disrupters. 1-Analytical strategy for estrogens measurement in plasma at ultra-trace level. Analytica Chimica Acta 586:105-114.

Daxenberger A, Ibarreta D, Meyer H. 2001. Possible health impact of animal oestrogens in food. Human Reproduction Update 7:340-355.

French JB, Nisbet I, Schwabl H. 2001. Maternal steroids and contaminants in common tern eggs: a mechanism of endocrine disruption? Comparative Biochemistry and Physiology C 128:91-98.

Gaiani R, Chiesa F, Mattioli M, Nannetti G, Galeati G. 1984. Androstenedione and testosterone concentrations in plasma and milk of the cow throughout pregnancy. Journal of Reproduction and Fertility 70:55-59.

Hartmann S, Lacorn M, Steinhart H. 1998. Natural occurrence of steroid hormones in food. Food Chemistry 62:7-20. 
Janzen FJ, Wilson ME, Tucker JK, Ford SP. 1998. Endogenous yolk-steroid hormones in turtles with different sex-determining mechanisms. General and Comparative Endocrinology 111:306-317.

Jenner MR, Kelch RP, Kaplan SL, Grumbach MM. 1972. Hormonal changes in puberty. IV. Plasma estradiol, LH and FSH in prepubertal children, pubertal females, and in precocious puberty, premature thelarche, hypogonadism, and in a child with a feminizing ovarian tumor. Journal of Clinical Endocrinology and Metabolism 34:521530.

Juul A. 2001. The effets of estrogens on linear bone growth. Human Reproduction Update 7:303-313.

Lipar J, Ketterson E, Nolan V. 1999. Egg yolk layers vary in the concentration of steroid hormones in two avian species. General and Comparative Endocrinology $115: 220-227$. 
MacGarrigle, Lachelin. 1983. Oestrone, oestradiol and oestriol glucosiduronates and sulphates in human puerperal plasma and milk. Journal of Steroid Biochemistry and Molecular Biology 18:607-611.

Narendran R, Hacker R, Smith V, Lun A. 1979. Estrogen and progesterone concentrations in bovine during the estrous cycle. Theriogenology 12:19-25.

Nelson R, Grebe S, O'Kane D. 2004. Liquid chromatography - tandem mass spectrometry assay for simultaneous measurement of estradiol and estrone in human plasma. Clinical Chemistry 50:373-384.

Petrie M, Schwabl H, Brande-Lavridsen N, Burke T. 2001. Sex differences in avian yolk hormone levels. Nature 412:498.

Saumande J, Batra S. 1984. A double antibody radioimmunaossay for free and conjugated estradiol-17 $\beta$ in cow's milk. Steroids 44:137-139. 
Table I: GC-MS/MS acquisition parameter used for the measurement of estrogens (Negative chemical ionisation; PFB-TMS derivatisation) and Androgens (Electron ionisation; TMS derivatisation)

\begin{tabular}{|c|c|c|c|}
\hline Analytes & Transition & Collision Energy (eV) & RT (min) \\
\hline $17 \alpha$-estradiol & $343>343$ & 20 & 21.25 \\
\hline $17 \beta$-estradiol & $343>343$ & 20 & 21.94 \\
\hline Estrone & $269>269$ & 20 & 21.78 \\
\hline $17 \beta$-estradiol-d $d_{3}$ (Internal Standard) & $346>346$ & 20 & 21.91 \\
\hline Estriol (External Standard) & $431>431$ & 20 & 24.30 \\
\hline \multirow{2}{*}{ Dehydroepiandrosterone } & $432.3>327.3$ & 10 & \multirow{2}{*}{17.03} \\
\hline & $432.3>417.4$ & 5 & \\
\hline \multirow{3}{*}{$17 \alpha$-testosterone } & $432.3>247.2$ & 15 & \multirow{3}{*}{17.40} \\
\hline & & & \\
\hline & $432.3>209.2$ & 8 & \\
\hline \multirow{2}{*}{$17 \beta$-testosterone } & $432.3>247.2$ & 15 & \multirow{2}{*}{17.94} \\
\hline & $432.3>209.2$ & 8 & \\
\hline \multirow{3}{*}{ 4-androstenedione } & $430.3>415.3$ & 5 & \multirow{3}{*}{17.75} \\
\hline & & & \\
\hline & $430.3>209.2$ & 10 & \\
\hline $17 \alpha$-methyltestosterone- $d_{3}$ (Internal & & & \\
\hline & $449.3>301.2$ & 5 & 19.04 \\
\hline \multicolumn{4}{|l|}{ Standard) } \\
\hline Norgestrel (External Standard) & $456.3>316.2$ & 5 & 20.07 \\
\hline
\end{tabular}


Table IIa: Estrogens concentrations measured in milk $(\mathrm{n}=12)$

\begin{tabular}{ccccc}
\hline \multirow{2}{*}{ Analytes } & $\begin{array}{c}\text { Mean concentration }\left(\mathrm{ng} \mathrm{L}^{-1}\right) \pm \\
\text { standard deviation }\end{array}$ & $\begin{array}{c}\text { Min value } \\
\left(\mathrm{ng} \mathrm{L}^{-1}\right)\end{array}$ & $\begin{array}{c}\text { Max value } \\
\left(\mathrm{ng} \mathrm{L} \mathbf{L}^{-1}\right)\end{array}$ & \% Conjugates \\
\hline estrone & $152.8 \pm 60.0$ & 75.8 & 277.5 & 96 \\
\hline$\alpha$-estradiol & $39.4 \pm 10.7$ & 28.0 & 63.6 & 94 \\
\hline$\beta$-estradiol & $23.0 \pm 12.6$ & 9.8 & 44.3 & 84 \\
\hline
\end{tabular}

Table IIb: Free androgens concentrations measured in milk (17 $\beta$-testosterone concentrations are not described because only total $17 \beta$-testosterone was quantified in milk samples).

\begin{tabular}{|c|c|c|c|c|c|c|c|c|c|c|}
\hline \multirow[t]{2}{*}{ Type of milk } & \multirow[t]{2}{*}{$\mathrm{n}=$} & \multicolumn{3}{|c|}{ Dehydroepiandrosterone (ng L-1) } & \multicolumn{3}{|c|}{$\alpha$-testosterone (ng L-1) } & \multicolumn{3}{|c|}{ 4-androstenedione (ng L-1) } \\
\hline & & meantsd & $\begin{array}{l}\text { Min } \\
\text { Value }\end{array}$ & $\begin{array}{l}\text { Max } \\
\text { Value }\end{array}$ & meantsd & $\begin{array}{c}\text { Min } \\
\text { Value }\end{array}$ & $\begin{array}{l}\text { Max } \\
\text { Value }\end{array}$ & meantsd & $\begin{array}{c}\text { Min } \\
\text { Value }\end{array}$ & $\begin{array}{l}\text { Max } \\
\text { Value }\end{array}$ \\
\hline Whole & 4 & $65.4 \pm 22.4$ & 38.28 & 91.71 & $78.1 \pm 21.8$ & 46.51 & 94.86 & $934.3 \pm 270.9$ & 593.92 & 1218.9 \\
\hline $1 / 2$ Skimmed & 5 & $52.7 \pm 18.0$ & 36.48 & 67.19 & $51.3 \pm 17.0$ & 40.88 & 77.67 & $533.8 \pm 101.4$ & 453.89 & 676.15 \\
\hline Skimmed & 3 & $34.0 \pm 12.4$ & 20.85 & 52.54 & $31.8 \pm 3.6$ & 27.46 & 36.01 & $296.3 \pm 86.5$ & 191.56 & 400.62 \\
\hline
\end{tabular}


Table III: Estrogens and androgens concentrations measured in hens eggs $(\mathrm{n}=8)$

\begin{tabular}{cccc}
\hline Analytes & $\begin{array}{c}\text { Mean Concentration }\left(\mu \mathrm{g} \mathrm{kg}^{-1}\right) \pm \\
\text { standard deviation }\end{array}$ & Min value & Max value \\
& $1.44 \pm 0.27$ & 1.09 & 1.91 \\
\hline estrone & $0.55 \pm 0.15$ & 0.39 & 0.85 \\
\hline$\alpha$-estradiol & $0.91 \pm 0.29$ & 0.47 & 1.45 \\
\hline$\beta$-estradiol & $1.48 \pm 0.63$ & 0.94 & 2.68 \\
\hline Dehydroepiandrosterone & $1.94 \pm 0.31$ & 1.54 & 2.62 \\
\hline$\alpha$-testosterone & & & 1.56 \\
\hline$\beta$-testosterone & $1.33 \pm 0.19$ & 1.06 & 125.2 \\
\hline 4-androstenedione & $85.0 \pm 22.3$ & 55.8 & \\
\hline
\end{tabular}


a) calibration curves observed for $17 \mathrm{a}$-estradiol, $17 \beta$-estradiol and estrone in the 0 to $50 \mu \mathrm{kg}-1$ concentration range in egg sample b) calibration curves observed for $17 \mathrm{a}$-testosterone, $17 \beta$ testosterone, androstenedione and DHEA in the 0 to $50 \mu \mathrm{gg}-1$ concentration range in egg sample $674 \times 928 \mathrm{~mm}(96 \times 96 \mathrm{DPI})$ 
a) diagnostic ion chromatogram observed for a milk sample in which $17 \mathrm{a}$-testosterone and $17 \beta$ testosterone (upper trace) were quantified at 87 and $13 \mathrm{ng} \mathrm{kg}-1$, respectively. Androstenedione (lower trace) was quantified at $536 \mathrm{ng} \mathrm{kg-1} \mathrm{b)} \mathrm{diagnostic} \mathrm{ion} \mathrm{chromatogram} \mathrm{observed} \mathrm{for} \mathrm{an} \mathrm{egg}$ sample in which $17 \mathrm{a}$-estradiol and $17 \beta$-estradiol were quantified at 0.85 and $0.87 \mu \mathrm{g} \mathrm{kg}-1$, respectively.

$674 \times 928 \mathrm{~mm}(96 \times 96 \mathrm{DPI})$ 